\title{
Identification of viral hemorrhagic septicemia virus isolated from Pacific cod Gadus macrocephalus in Prince William Sound, Alaska, USA
}

\author{
T. R. Meyers ${ }^{1}$, J. Sullivan ${ }^{2}$, E. Emmenegger ${ }^{2}$, J. Follett ${ }^{2}$, S. Short ${ }^{1}$, W. N. Batts ${ }^{3}$, \\ J. R. Winton ${ }^{3}$
}

\begin{abstract}
${ }^{1}$ Alaska Department of Fish and Game, Division of Fisheries Rehabilitation, Enhancement and Development (F.R.E.D.), Fish Pathology Section, Juneau Fish Pathology Laboratory, PO Box 25526, Juneau, Alaska 99802, USA

${ }^{2}$ Alaska Department of Fish and Game, Division of Fisheries Rehabilitation, Enhancement and Development (F.R.E.D.), Fish Pathology Section, Anchorage Fish Pathology Laboratory, 333 Raspberry Road, Anchorage, Alaska 99518, USA ${ }^{3}$ U.S. Fish and Wildlife Service, National Fisheries Research Center, Building 204, Naval Station, Seattle, Washington 98115 ,
\end{abstract} USA

\begin{abstract}
Ulcerative skin tissues from 2 Pacific cod Gadus macrocephalus caught in Prince William. Sound, Alaska, USA, were examined for virus by Fish Pathology staff within the F.R.E.D. Division of the Alaska Department of Fish and Game. Six days after inoculation of Epithelioma papulosum cyprini (EPC) cells at $14^{\circ} \mathrm{C}$, diffuse rounding and lifting of cells from the monolayers suggestive of cytopathic effect became visible in the lower sample dilutions. Ultrastructural examinations of affected EPC cells showed rhabdovirus particles within cytoplasmic vacuoles and on the cell surface membranes. Virus isolates from both cod were subsequently confirmed as viral hemorrhagic septicemia virus (VHSV) by serum neutralization and immunoblot assay. This is the first VHSV isolated from Pacific cod, which represents a new host species for the virus. Histologically, cod skin ulcers appeared to be caused by a foreign-body-type inflammatory response to foci of protozoa resembling $X$ cells that also had plasmodial stages. Whether the rhabdovirus was incidental to the skin lesion or played a role in its etiology remains to be determined. The possible relationship between this virus and the recent occurrences of VHSV in anadromous salmonids from Washington State, USA, is discussed.
\end{abstract}

\section{INTRODUCTION}

In March 1988, an adult Pacific cod Gadus macrocephalus exhibiting large raised rounded skin papules, some of which were ulcerated with central craters, was caught near the Channel Island area in Prince William Sound, Alaska. In August 1990 and 1991 near the same location a second and third adult cod were caught having smaller, less elevated skin papules, some of which were ulcerated with central hemorrhaging. A rhabdovirus serologically identified as viral hemorrhagic septicemia virus (VHSV) F1 strain was isolated from the skin lesion material obtained from both cod.

The skin lesions described were similar to those reported for the Ulcus Syndrome in Atlantic cod Gadus morhua from Denmark (Jensen \& Larsen 1979, Jensen et al. 1979) from which VHSV F1 and an iridovirus-like agent were isolated.

\section{MATERIALS AND METHODS}

Virology and cell culture. A $1 \mathrm{~cm}^{3}$ portion of integumentary lesion material was aseptically removed from the affected cod in 1990 and placed into a vial of cold $\left(4^{\circ} \mathrm{C}\right)$ Eagle's minimum essential medium containing final concentrations of $50 \mu \mathrm{g}$ gentamycin $\mathrm{ml}^{-1}, 2.5 \mu \mathrm{g}$ amphotericin $\mathrm{B} \mathrm{ml} \mathrm{ml}^{-1}, 0.3 \%$ of tryptose phosphate broth, $0.04 \mathrm{mM}$ supplemented L-glutamine $\mathrm{ml}^{-1}$ and 8.9 to $14.3 \mathrm{mM}$ sodium bicarbonate (MEM-0). One day later, the tissue was homogenized in a Con Torque 
grinder, diluted 1:10 (w/v) with MEM-0 and centrifuged at $2000 \times g$ for $20 \mathrm{~min}$. Epithelioma papulosum cyprini (EPC) cell (Fijan et al. 1983) monolayers were grown up in a 24 -well plate in MEM-0 containing $10 \%$ (MEM-10) fetal bovine serum (FBS) at $23^{\circ} \mathrm{C}$. Cells were pretreated with polyethylene glycol (PEG) (Batts \& Winton 1989) for $10 \mathrm{~min}$ at room temperature (23 to $25^{\circ} \mathrm{C}$ ), then triplicate wells were inoculated with $0.1 \mathrm{ml}$ volumes of undiluted and 1:10 diluted supernatant from the homogenized lesion material. Inoculum was adsorbed onto cells for $1 \mathrm{~h}$ at $14^{\circ} \mathrm{C}$ before addition of $1 \mathrm{ml}$ per well of MEM-10 and a final concentration of $15 \mathrm{mM}$ tris buffer and $5.4 \mathrm{mM}$ sodium bicarbonate. The plate of cells was incubated at 14 to $15^{\circ} \mathrm{C}$ in a sealed plastic bag

The second cod sample in 1991 was received as a whole fish, from which skin lesion material and a spleen/kidney pooled sample were homogenized and inoculated onto EPC cells as above. However, a third 1:100 dilution of supernatant fluid from homogenized samples was added and all samples were done in duplicate. After $14 \mathrm{~d}$ of incubation at $14^{\circ} \mathrm{C}$ a blind passage of the kidney/spleen inoculated cultures was done using $0.1 \mathrm{ml}$ of cell suspension and supernatant from the first dilution wells. This blind passage was terminated after $22 \mathrm{~d}$ of incubation.

Plaque formation ability under a methylcellulose overlay was examined using EPC cells grown in 24well plates (Burke \& Mulcahy 1980). These cells were infected with dilutions of $10^{0}$ to $10^{-5}$ of the initial culture fluid from wells showing cytopathic effect (CPE), and incubated at $14^{\circ} \mathrm{C}$. Virus titers were also compared in the chinook salmon embryo (CHSE-214) (ATCC CRL 1681) and bluegill fry (BF-2) (Wolf et al. 1966) cell lines. Supernatant of fourth passage material from an EPC well showing complete destruction of the cell monolayer was titrated using the microtiter system with EPC, CHSE-214 and BF-2 cells. Virus titers in each cell line were determined by the TCID $_{50}$ method of Reed \& Muench (1938).

Transmission electron microscopy (TEM). Remnants of EPC monolayers showing extensive CPE from both the 1990 and 1991 samples were scraped off and fixed 16 to $18 \mathrm{~h}$ in cold $\left(4^{\circ} \mathrm{C}\right) 4 \%$ glutaraldehyde in $0.1 \mathrm{M}$ cacodylate buffer $(\mathrm{pH} 7.8)$. Cells were post-fixed in cacodylate-buffered $1 \%$ osmium tetroxide for $1 \mathrm{~h}$ at $4^{\circ} \mathrm{C}$. The fixed material was dehydrated through a series of ethanol solutions and embedded in Spurr's low viscosity resin. Ultra-thin sections mounted on 300 mesh grids were stained in $4 \%$ uranyl acetate and $2.6 \%$ lead citrate and observed at $80 \mathrm{kV}$ with a Philips TEM 300

Serology. Virus neutralization: Plaque reduction serum neutralization tests were performed using polyvalent rabbit antisera prepared against the hirame rhabdovirus (HRV) (from T Nishizawa, Hokkaido University, Japan), the European F1 reference strain of VHSV from P. MCAllister, National Fisheries Research Center, Leetown, West Virginia, USA) and a Cedar River, Washington, isolate of infectious hematopoietic necrosis virus (IHNV) (from National Fisheries Research Center, Seattle, Washington, USA). Each antiserum was tested against the fourth passage material of the cod isolate taken in 1990, HRV (from T. Nishizawa), the Cedar River isolate of IHNV (from National Fisheries Research Center, Seattle), and a VHSV isolate (from National Fisheries Research Center, Seattle) from the Makah National Fish Hatchery, near Neah Bay, Washington, USA. Third passage material of the cod isolate taken in 1991 was similarly tested against the VHSV and IHNV antisera. Briefly, viruses were diluted to $2 \times 10^{5}$ plaque-forming units (PFU) $\mathrm{ml}^{-1}$. Equal volumes $(200 \mu \mathrm{l})$ of antisera prepared at a dilution of 1:50 were mixed with each virus dilution in a 24-well plate. Virus suspensions incubated with equal volumes of MEM-0 served as controls. The mixtures were gently agitated at room temperature for $1 \mathrm{~h}$. Each virus/antiserum mixture and virus/MEM control were inoculated at dilutions of $10^{\circ}$ to $10^{-3}$ onto replicate wells of PEG-treated EPC cells in 8-well plates for an adsorption period of $30 \mathrm{~min}$ at room temperature. The inoculum was not removed and infected cells were overlaid with $2 \mathrm{ml}$ volumes of MEM-5-tris (5\% FBS) containing $0.75 \%$ methylcellulose and $3.6 \mathrm{mM}$ sodium bicarbonate. Plates were then incubated for $7 \mathrm{~d}$ at $15^{\circ} \mathrm{C}$

Immunosorbent assay: An immunoblot version of an enzyme-linked immunosorbent assay was performed on the third and fourth passages of both cod isolates using the methods of McAllister \& Schill (1986). The undiluted isolates in tissue culture fluid were spotted onto nitrocellulose strips pre-wetted with $0.1 \mathrm{M}$ PBS and allowed to dry for $5 \mathrm{~min}$. Two isolates of IHNV (Kitoi Bay and Little Sisitna River, Alaska, USA) collected by F.R.E.D. Pathology staff, PBS and MEM-10tris media from CHSE-214 and EPC cell cultures were included as controls. The spotted strips were immersed in buffer containing $3 \%$ immunoassay grade gelatin for $20 \mathrm{~min}$ at $37^{\circ} \mathrm{C}$ to block nonspecific sites and transferred to a 1:1000 dilution of polyvalent rabbit anti-VHS virus serotype $\mathrm{F} 1$ primary antibody at $37^{\circ} \mathrm{C}$ for $60 \mathrm{~min}$. The primary antibody had been diluted previously with PBS containing $30 \%$ fetal bovine serum and adsorbed overnight at $37^{\circ} \mathrm{C}$ in a $150 \mathrm{~cm}^{2}$ flask of CHSE-214 cells to eliminate nonspecific reactivity with fetal bovine serum and fish cell antigens. Afterwards, the strips were washed in 3 changes of $0.1 \mathrm{M}$ PBS containing $0.02 \%$ Tween 20 for $30 \mathrm{~min}$. This was followed by incubation for $60 \mathrm{~min}$ at $37^{\circ} \mathrm{C}$ with a $1: 1000$ PBS dilution of an affinity purified goat anti-rabbit IgG antibody 
conjugated with horseradish peroxidase (Cappel, USA). The strips were again washed for $30 \mathrm{~min}$ in PBSTween 20 as above and immersed for $3 \mathrm{~min}$ in a hydrogen peroxide 4-chloro-naphthol color developing solution. Color development was carried out in a dark room followed by washing in running tap water for 15 min.

A second immunoblot test was performed with similar samples but using a Bio-Dot microfiltration apparatus (Bio-Rad, USA) to apply up to $100 \mu \mathrm{l}$ of each sample. The primary antibody in this case was a monoclonal against IHNV (National Fisheries Research Center, Seattle) followed by a goat anti-mouse IgG horseradish peroxidase (HRP) conjugate (Bio-Rad, USA). Procedures and other reagents used were those provided in a Bio-Rad immunoblot assay kit for goat anti-mouse HRP conjugate. Results were photographed using $35 \mathrm{~mm}$ Kodak Tmax 400 black and white film.

Bacteriology. A skin lesion on the affected cod in 1990 was lightly swabbed with $70 \%$ alcohol followed by an incision with a sterile scalpel blade to expose subsurface lesion material. A sterile cotton swab wiped across this cut surface was struck onto a slant of tryptose soy agar (TSA) that was kept on ice. The following day the slant was incubated at $20^{\circ} \mathrm{C}$ for $6 \mathrm{~d}$.
Histology. Another $1 \mathrm{~cm}^{3}$ portion of lesion material from the fish caught in 1990 similar to that taken for virology was placed into Bouin's fixative and a portion processed for standard histological examination.

\section{RESULTS}

\section{Virus isolation}

Cytopathic effects were evident on EPC cells $6 \mathrm{~d}$ post-inoculation at $14^{\circ} \mathrm{C}$ using cod lesion material from both fish caught in 1990 and 1991. The CPE was diffuse, consisting of rounded refractile cells (Fig. 1) that dislodged from the monolayer, resulting in total destruction of the cell sheets by $8 d$ in the undiluted and 1:10 dilution wells. Passage of this original material from the 1990 fish gave plaque titers (PFU) of $1.0 \times 10^{5}$ within $5 \mathrm{~d}$. The minimum level of virus necessary for detection in the original sample was estimated to be 50 infectious particles per gram of tissue.

Despite isolation of virus from skin lesions of the cod taken in 1991, the spleen/kidney pool from the same fish failed to produce a detectable isolate

Virus titers from fourth passage material of the 1990

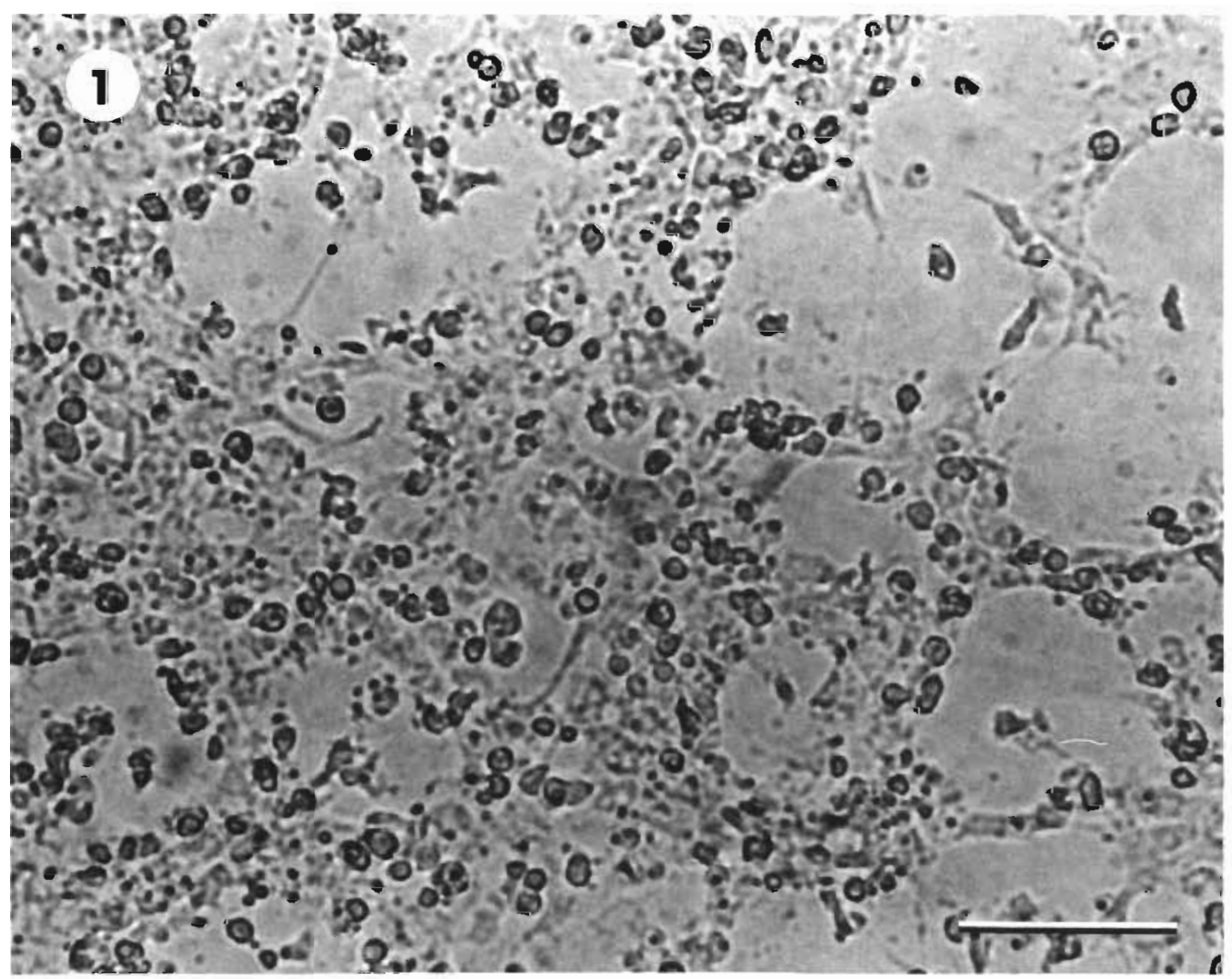

Fig. 1. Cytopathic effect of EPC cells infected with the VHSV isolate from Pacific cod Gadus macrocephalus showing diffuse retraction and rounded refractile cells; scale bar $=100 \mu \mathrm{m}$ 
isolate infecting EPC, BF-2 and CHSE-214 cells are presented in Table 1. After $8 \mathrm{~d}$ virus titers in EPC and $\mathrm{BF}-2$ cells were comparable but virus yield in the CHSE-214 cells was ca $1 \log _{10}$ lower.

Table 1. Titers $\left(\mathrm{TCID}_{50}\right)$ of the 1990 virus isolate from Pacific cod Gadus macrocephalus (fourth passage) after $8 \mathrm{~d}$ of incubation at $14^{\circ} \mathrm{C}$ on EPC, BF-2 and CHSE-214 cell lines

\begin{tabular}{|lc|}
\hline Cell line & TCID $_{50} \mathrm{ml}^{-1}$ \\
\hline EPC & $6.4 \times 10^{7}$ \\
BF-2 & $3.8 \times 10^{7}$ \\
CHSE-214 & $1.6 \times 10^{6}$ \\
\hline
\end{tabular}

\section{Transmission electron microscopy}

EPC cells inoculated with both isolates showed numerous rhabdovirus-like particles free within cytoplasmic vacuoles, on cell surfaces (Fig. 2) and budding from the cytoplasm membranes. Most particles were comparable in morphology and dimensions (60 to 70 $\mathrm{nm} \times 170$ to $180 \mathrm{~nm})$ to most reported fish rhabdoviruses (Wolf 1988). Longer particles measured up to $400 \mathrm{~nm}$ and tended to have somewhat smaller diameters (Fig. 3). The flat ends of some particles tended to each have a pair of clamp-like projections extending from either side. Also notable were the abundant cytoplasmic foci of what appeared to be unassembled

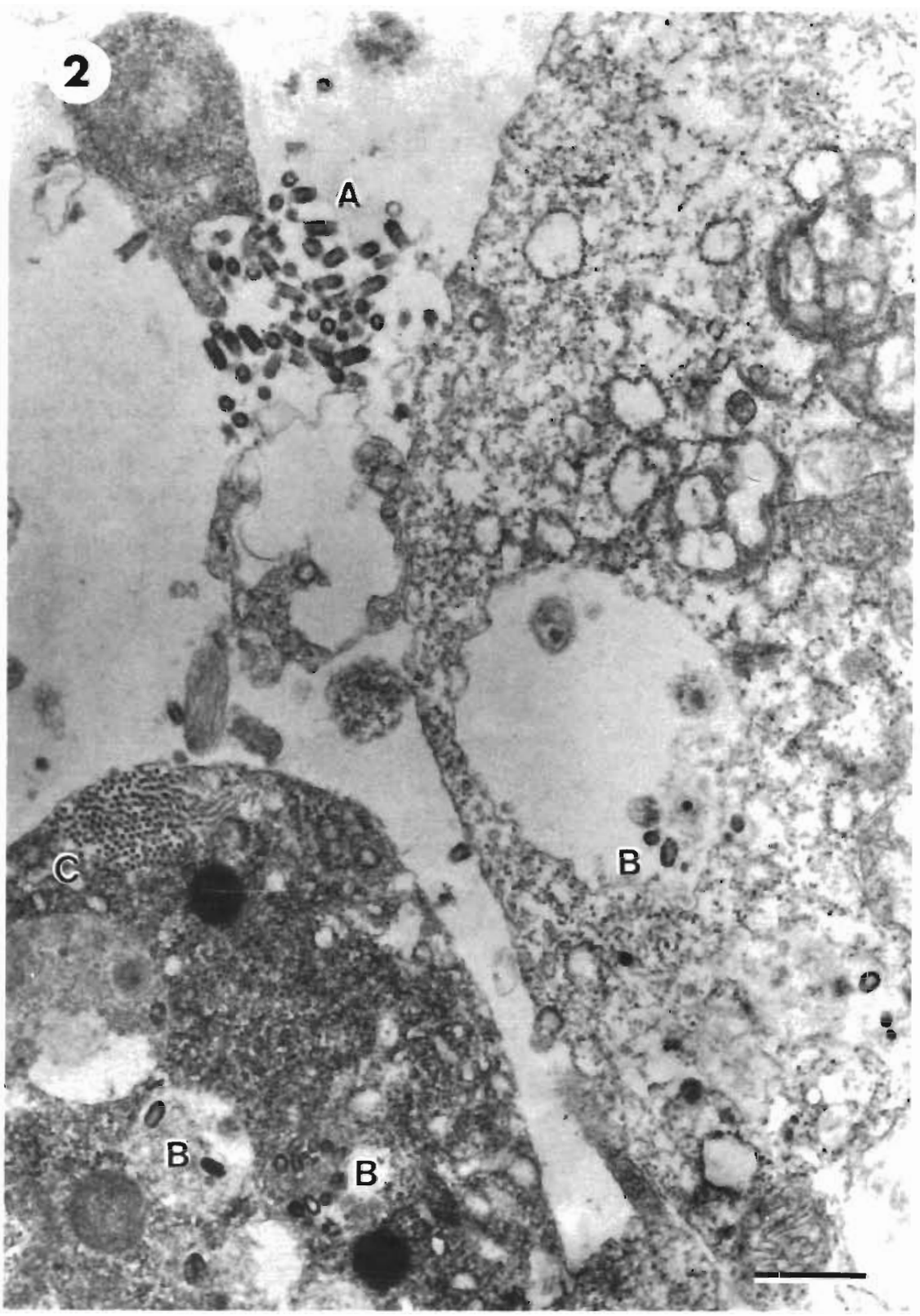

Fig. 2. Electron micrograph of an EPC cell infected with VHSV isolate from Gadus macrocephalus showing bulletshaped viral particles (A) outside the cell and (B) within cell vacuoles, and (C) probable unassembled nucleocapsids within the cytoplasm; scale bar = $1 \mu \mathrm{m}$ 


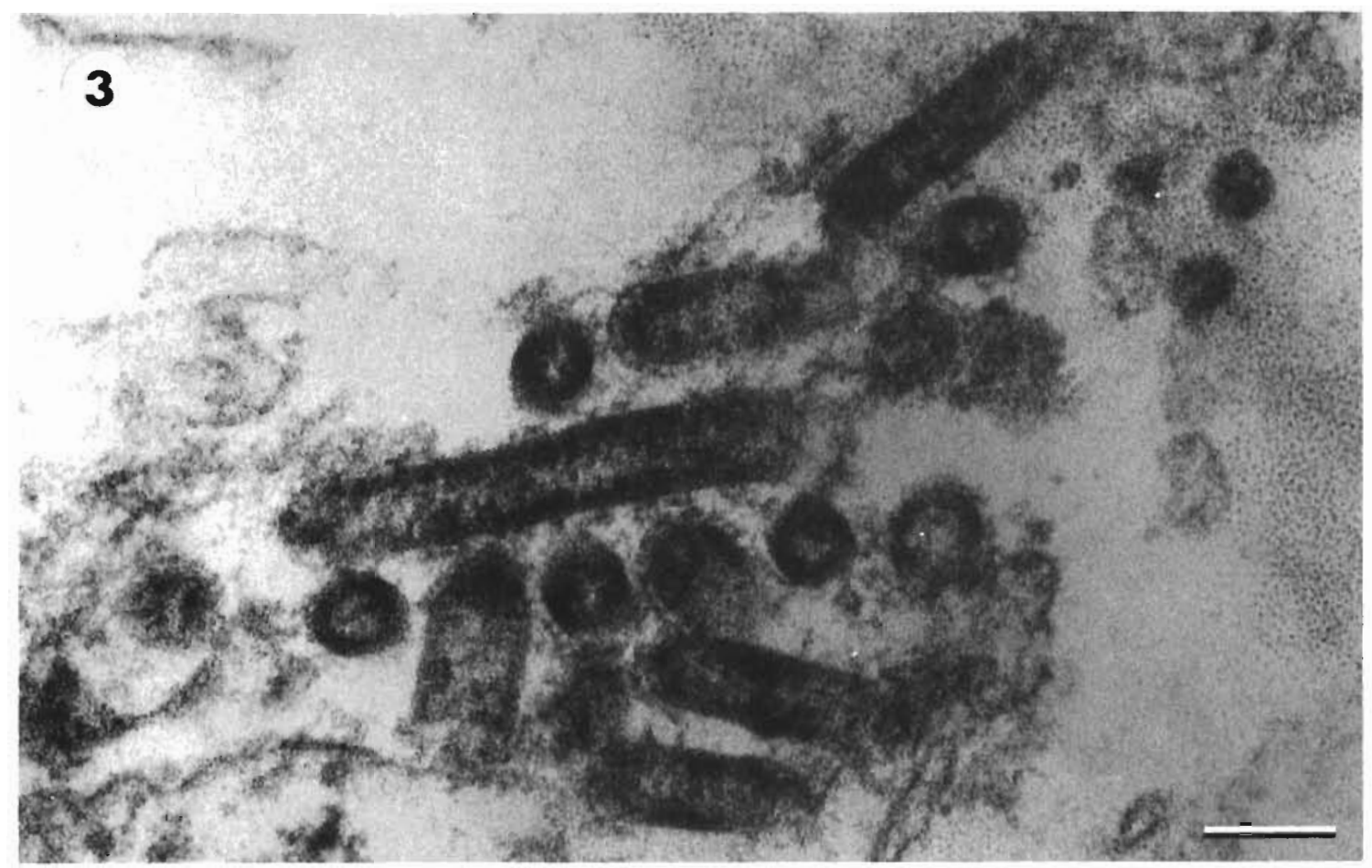

Fig. 3. Electron micrograph of the VHSV isolate from Pacific cod Gadus macrocephalus in EPC cell debris showing long virus particles $(400 \mathrm{~nm})$; scale bar $=0.1 \mu \mathrm{m}$

nucleocapsid material in transverse and longitudinal profiles (Fig. 2).

\section{Serology}

Results of the plaque reduction tests for both the 1990 and 1991 cod isolates are presented in Table 2 as neutralization indices. Both isolates were clearly neutralized by at least $4 \log _{10}$ by the antiserum against the European VHSV F1 strain. All control viruses were significantly neutralized only by their homologous antisera.
The first immunoblot assay resulted in blue-gray spots containing the antigens of the virus isolates from cod. No color was observed on the IHNV or negative control samples when stained with the anti-VHSV primary antiserum (Fig. 4). One exception was a very faint nonspecific crossreaction noted in an IHNV sample from CHSE-214 cells. No such crossreaction was observed with the same IHNV isolate replicated in EPC cells (Fig. 4). Use of the monoclonal anti-IHNV antibody resulted in reversed results, i.e. positive signals for the IHNV samples and no color development for the 2 virus isolates from cod or negative control samples (Fig. 4).

Table 2. Serum neutralization indices $\left(\log _{10}\right)$ for the 1990 and 1991 isolates of viral hemorrhagic septicemia virus (VHSV) from Alaskan Pacific cod Gadus macrocephalus using normal tissue culture fluid (MEM) and antisera against the European reference F1 strain of VHSV, Japanese hirame rhabdovirus (HRV) and a Cedar River, Washington, isolate of infectious hematopoietic necrosis virus (IHNV). Homologous virus controls included the Makah National Fish Hatchery VHSV isolate instead of the European F1 reference strain. ND: not done

\begin{tabular}{|c|c|c|c|c|c|}
\hline \multirow{3}{*}{$\begin{array}{l}\text { Rabbit antisera } \\
\text { (diluted 1:100) }\end{array}$} & \multicolumn{5}{|c|}{ Viruses } \\
\hline & \multicolumn{2}{|c|}{ Cod VHSV, Alaska } & \multirow{2}{*}{$\begin{array}{l}\text { VHSV, Makah, } \\
\text { Washington }\end{array}$} & \multirow[t]{2}{*}{ HRV, Japan } & \multirow{2}{*}{$\begin{array}{c}\text { IHNV, Cedar R., } \\
\text { Washington }\end{array}$} \\
\hline & 1990 & 1991 & & & \\
\hline HRV & 0 & ND & 0.2 & 2.4 & 0 \\
\hline VHSV F1 & $>4.0$ & 5.1 & $>3.8$ & 0 & 0 \\
\hline IHNV & 0 & 0 & 0.4 & 0.1 & 2.8 \\
\hline MEM & 0 & 0 & 0 & 0 & 0 \\
\hline
\end{tabular}




\section{Bacteriology}

The bacteriological media inoculated with losion material did not exhibit any bacterial growth during the $6 \mathrm{~d}$ incubation period.

\section{Histology}

Histological examination of the cod ulceration showed several elements comprising the lesion. The dermis contained large foci of what first appeared as degenerate thick-walled, X-type cells (Alpers et al. 1977. Morrison et al. 1982) filled with debris surrounded by inflammatory infiltrate including tubercles of epithelioid cells (Fig. 5). Some tubercles contained necrotic centers, occasional bacterial organisms, or X-type cells. Accompanying fibroplasia was evident with hemorrhage, necrosis and edema within the scale beds. On close examination of the epidermal-dermal border, the supposed X-cell outlines contained multiple nuclei rather than debris or a single nucleus, thus resembling plasmodial forms (Fig. 6). Plasmodia were also numerous within the edematous areas of scale beds. Whether these forms represent a sporozoan parasite or yet another form of the X-cell remains to be determined. The epidermis was raised by the protistan foci and accompanying inflammatory exudate forming a papule with ulceration of the epidermis. The underlying subcutis and skeletal musculature were not involved with tubercles or protozoa. However, one section did show a granuloma within skeletal musculature, possibly from some other unrelated cause.

Fig. 4. Nitrocellulose strips spotted with 2 VHSV isolates from Pacific Gadus macrocephalus and 4 isolates of IHNV stained with polyclonal rabbit anti-VHSV (I and II) and monoclonal anti-IHNV antisera (IIL). All viruses were replicated in EPC cells except where noted otherwise Strip I: (1) PBS; (2) MEM 10; (3) MEM 10 from CHSE-214 cells (upper left) and EPC cells (lower right); (4) \& (6) Kitoi Bay IHNV; (5) \& (8) VHSV isolate from Pacific cod (1990); (7) Trapper Lake IHNV in ovarian fluid that has clogged the membrane. Strip II: (1) MEM 10 from EPC cells; (2) CHSE-214 cells \& (5) EPC cells, Little Susitna River IHNV. Note slight nonspecific crossreaction of VHSV antiserum with IHNV sample from CHSE-214 cells (spot 2) due to incomplete antiserum adsorption with CHSE-214 cells; (3) Kitoi Bay IHNV; (4) PBS; (6) VHSV isolate from Pacific cod (1991). Strip III: Spots A1 and A2 contain Auke Creek IHNV; spots A3 and A4 contain Little Susitna River IHNV; spots B1 and B2 contain VHSV isolate from Pacific cod (1990); spots B3 and B4 contain VHSV isolate from Pacific cod (1991); spots C1 and C2 contain MEM 10 from EPC cells

\section{DISCUSSION}

Results from electron microscopy, serum neutralization and immunoblot tests confirmed that the 2 virus isolates from Pacific cod were VHSV and identical. The faint nonspecific crossreaction noted in one of the
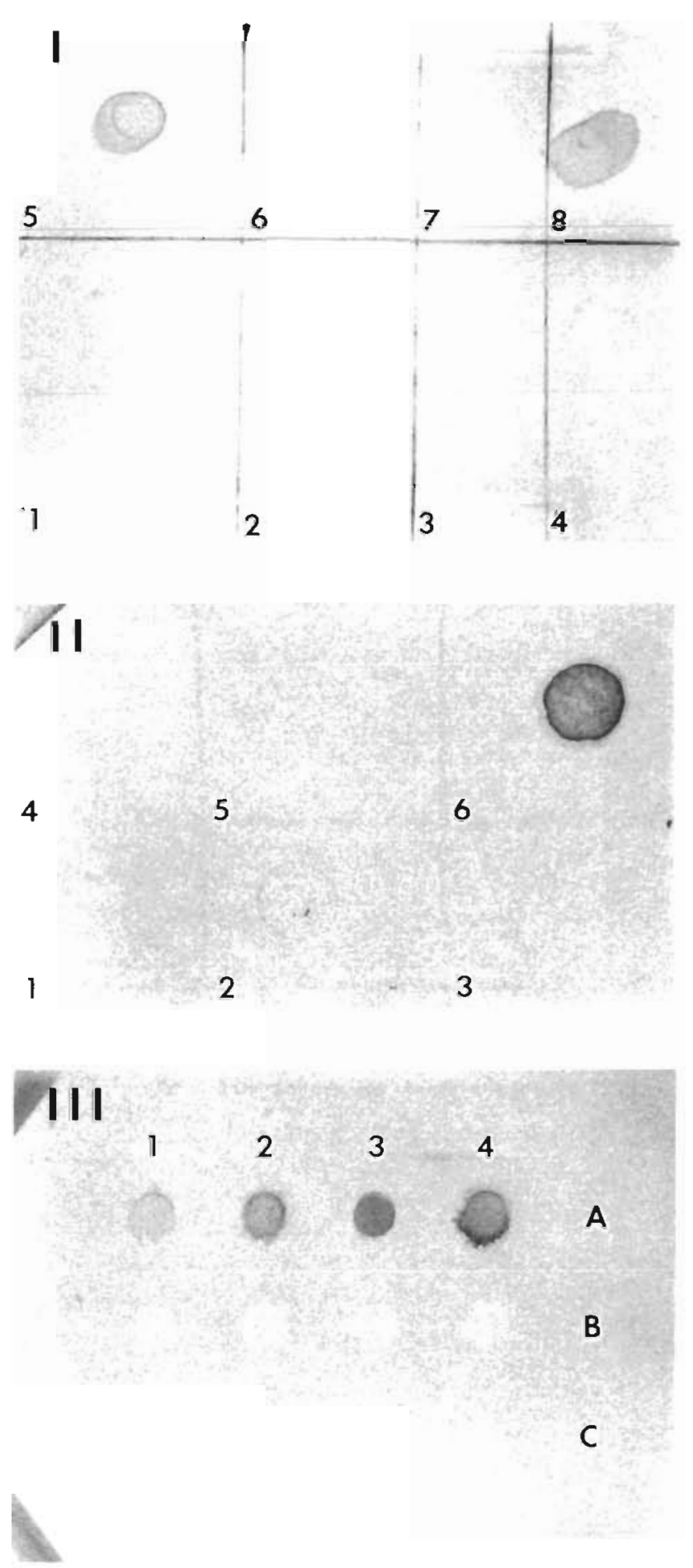


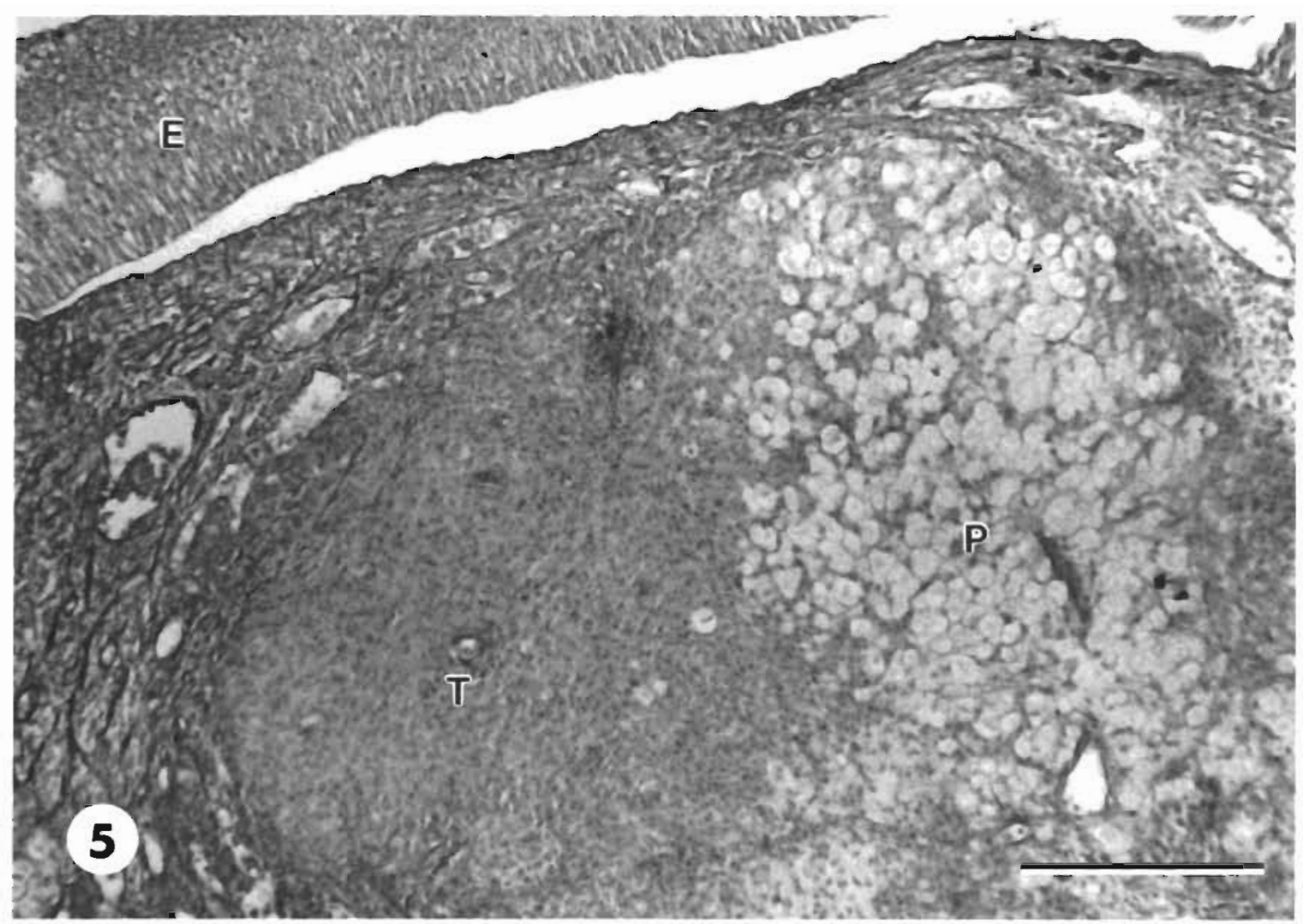

Fig. 5. Tissue section of skin lesion from Gadus macrocephalus showing intact epidermis (E) elevated by inflammatory exudate containing epithelioid cell tubercles $(T)$ and foci of degenerated X-type cells (P). H\&E; scale bar $=300 \mu \mathrm{m}$

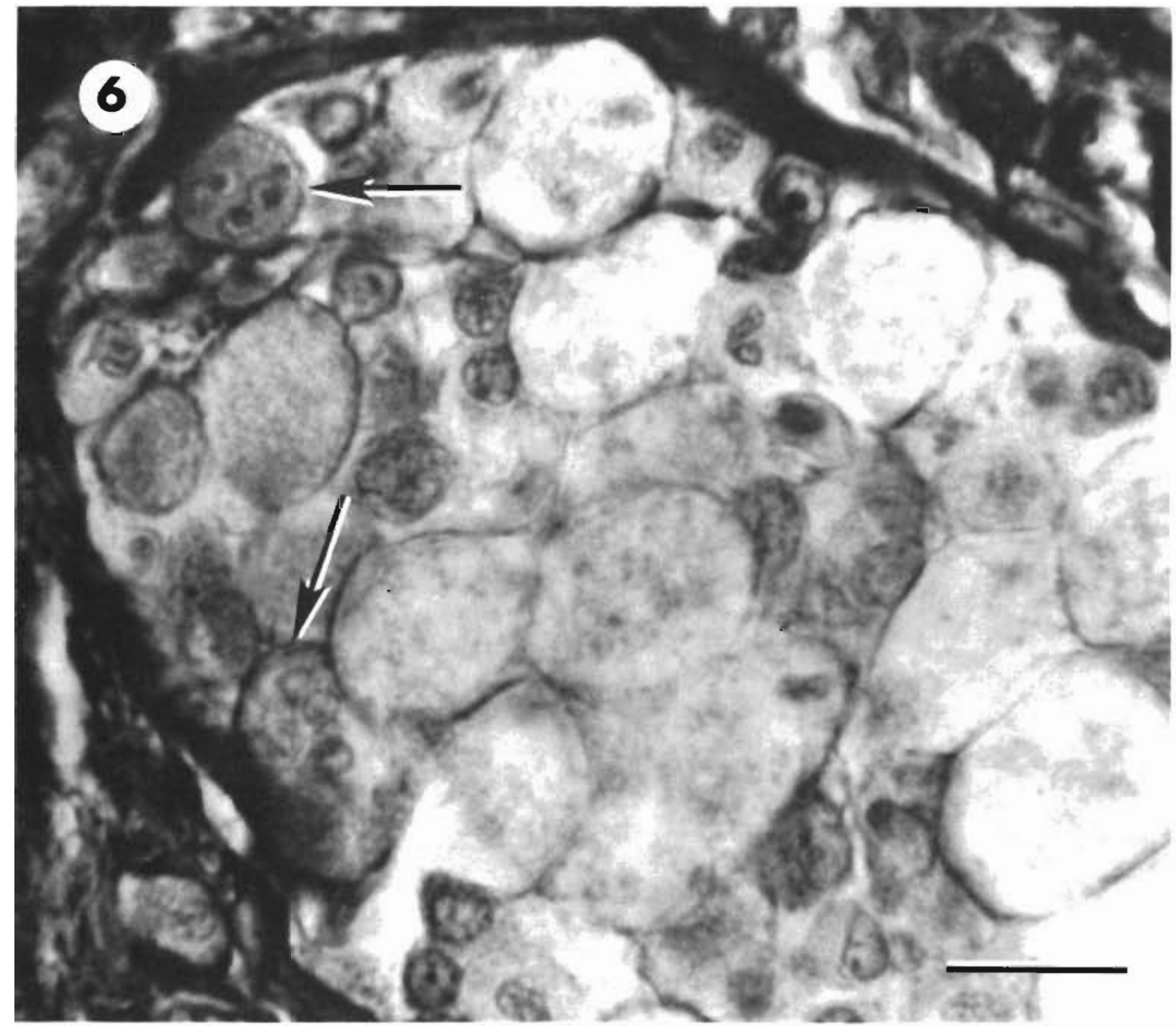

Fig. 6. Stained tissue section of Gadus macrocephalus skin lesion from Fig. 5 showing focus of degenerative X-type cells with possible earlier plasmodial stages (arrows). H\&E; scale bar $=20 \mu \mathrm{m}$ 
IHNV immunoblot samples was indicative of incomplete VHSV antiserum adsorption against CHSE-214 cells (McAllister \& Schill 1986). Although the VHSV antiserum used in the serological tests was specific for VHSV, it will apparently crossreact with all VHSV serotypes on immunoblot but will only neutralize the F1 strain (P. McAllister pers comm.). Whether VHSV from Pacific cod can be definitively identified as an F1 strain remains questionable based on recent studies involving neutralizing monoclonal and polyclonal antibodies against 90 European VHSV isolates (Olesen et al. 1991). This work suggests that the original serotyping of VHSV is still poorly defined.

Preliminary analysis using $T_{1}$ ribonuclease fingerprinting of the first YHSV isolate from Pacific cod and 4 VHSV isolates collected from salmon in Washington State (Brunson et al. 1989, Hopper 1989, Winton et al. 1989, Eaton \& Hulett 1990, Stewart et al. 1990) has shown that they differ genetically in their nucleic acid sequences from 4 European VHSV strains but show close genetic relatedness with each other (K. Oshima, University of Washington, Seattle, unpubl,). The isolation of VHSV from tissues and fluids of adult coho Oncorhynchus kisutch and chinook $O$. tshawytscha salmon returning to 4 geographically separate locations in Washington State during 1988 and 1989 may be explained by the presence of a marine reservoir for VHSV in North America. This hypothesis is supported by the results presented here and by previous studies showing that the Washington VHSV isolates were more stable in saltwater than freshwater and relatively avirulent for selected salmonids (Winton et al. 1991).

The rhabdovirus isolated from Atlantic cod with Ulcus Syndrome (Jensen et al. 1979) was identified as an F1 strain of VHSV using serum neutralization and immunofluorescence (Vestergard Jorgensen \& Olesen 1987). The virus was isolated only once from pooled lesion material from 7 cod in the second blind passage. Further sampling of similar skin lesions from Danish Atlantic cod failed to yield another isolate of the rhabdovirus, and additional isolates of the iridovirus were made, but inconsistently. A bacteriologic etiology for the Ulcus Syndrome was dismissed and a viral cause suspected after various laboratory studies (Jensen \& Larsen 1982). Experimental transmission of the skin lesions was successful in one trial when 6 healthy fish developed ulcers after cohabitation with 4 fish having Ulcus Syndrome lesions. Less success was achieved by injecting the cultured iridovirus, which only occasionally resulted in the skin lesions. Similar injection experiments with the rhabdovirus isolate failed to produce any lesions (Jensen \& Larsen 1982). Vestergard Jorgensen \& Olesen (1987) later suggested that the rhabdovirus isolate was VHSV of freshwater origin possibly contaminating cod surfaces or the cell cultures used.
This was based upon the apparent very low level of virus present on initial isolation, which needed 2 passages for visible CPE, and the restriction of VHSV at that time to pike Esox lucius and salmonid host species (Ahne \& Thomsen 1985).

We believe it very unlikely that the VHSV isolates from Pacific cod were contaminants since there have been no conceivable natural source/host species for the virus in Alaska other than the lesion material tested. Also VHSV, a previously restricted agent exotic to the USA, has never been used or present within the F.R.E.D. fish pathology laboratories so that cell contamination could occur, during the more than $14 \mathrm{yr}$ of program existence. Consequently, the Pacific cod isolates appear to be genuine and present a strong case for reconsideration of the Atlantic cod VHSV in the same context.

Except for the VHSV and iridovirus isolates from Danish Atlantic cod with Ulcus Syndrome (Jensen et al. 1979), no additional viruses have been cultured from cod until now. Electron microscopy has demonstrated a herpesvirus in Pacific cod from the Bering Sea (McArn et al. 1978) and 2 other viruses from Atlantic cod: viral erythrocytic necrosis (VEN) (Appy et al. 1976, Walker \& Sherburne 1977, Reno \& Nicholson 1980) and an adenovirus (Jensen \& Bloch 1980). Our virus isolates are the first VHSV isolates from Pacific cod, which also represents a new host species for VHSV.

Whether these isolates from Pacific cod represent a primary pathogen or secondary opportunistic agent within observed skin ulcers remains to be determined by future infection experiments. Presently, however, its apparent association with these lesions should not be ignored. European strains of VHSV, although targeting kidney tissue, can be isolated from other organs in acute infections (Wolf 1988). It is intriguing that both Pacific cod isolates were present in skin ulcers in reasonably high titers. Also interesting is that virus could not be detected from the spleen/kidney pool of the second cod, suggesting that the virus infection was not systemic but localized in the superficial skin lesion

The dermal lesion from our Pacific cod collected in 1990 appears to have been caused by tissue destruction from the protozoal plasmodial forms observed in the accompanying host inflammatory response. Other agents could have been involved since histological sections clearly indicated the presence of bacterial organisms as well. We were not able to isolate bacteria from this material, perhaps because the media was not specific enough or the topical disinfection eliminated too many organisms.

Acknowledgements. We thank Mrs Ruth Fairall of Cordova, Alaska, for her interest, diligence and professionalism in submitting the first cod sample on which this work was started. 


\section{LITERATURE CITED}

Ahne, W., Thomsen, L. (1985). Occurrence of VHS virus in wild white fish (Coregonus sp.). Zbl. Veterinärmed. Reihe B 32: 73-75

Alpers, C. E., McCain, B. B., Myers, M., Wellings, S. R., Pore, M., Bagshaw, J., Dawe, C. J. (1977). Pathologic anatomy of pseudobranch tumours in Pacific cod, Gadus marrocephalus. J. natn. Cancer Inst. 59: 377-398

Appy, R. G., Burt, M. D. B., Morris, T. J. (1976). Viral nature of piscine erythrocytic necrosis (PEN) in the blood of Atlantic cod (Gadus morhua). J. Fish. Res. Bd Can. 33: 1380-1385

Batts, W. N., Winton, J. R. (1989). Enhanced detection of infectious hematopoietic necrosis virus and other fish viruses by pretreatment of cell monolayers with polyethylene glycol. J. Aquat. Anim. Health 1: 284-290

Brunson, R., True, K., Yancey, J. (1989). VHS virus isolated at Makah National Fish Hatchery. Fish Health Sect. Am. Fish. Soc. Newsl. 17 (2): 3

Burke, J. A., Mulcahy, D. (1980). Plaquing procedure for infectious hematopoietic necrosis virus. Appl. environ. Microbiol. 39: 872-876

Eaton, W. D., Hulett, J. (1990). The fourth (and fifth?) isolation of viral hemorrhagic septicemia virus in Washington State. Fish Health Sect. Am. Fish. Soc. Newsl. 18 (1): 3

Fijan, N., Sulimanovic, D., Bearzotti, M., Muzinic, D., Zwillenberg, L. O., Chilmonczyk, S., Vautherot, J. F., de Kinkelin, P. (1983). Some properties of the Epithelioma papulosum cyprini (EPC) cell line from carp Cyprinus carpio. Ann. Virol. Inst. Pasteur 134: 207-220

Hopper, K. (1989). The isolation of VHSV from chinook salmon at Glenwood Springs, Orcas Island, Washington. Fish Health Sect. Am. Fish. Soc. Newsl. 17 (2): 1

Jensen, N. J., Bloch, B. (1980). Adenovirus-like particles associated with epidermal hyperplasia in cod (Gadus morhua). Nord. Veterinaermed. 32: 173-175

Jensen, N. J., Bloch, B., Larsen, J. L. (1979). The ulcussyndrome in cod (Gadus morhua). III. A preliminary virological report. Nord. Veterinaermed. 31: 436-442

Jensen, N. J., Larsen, J. L. (1979). The ulcus-syndrome in cod (Gadus morhua) I. A pathological and histopathological study. Nord. Veterinaermed. 31: 222-228

Jensen, N. J., Larsen, J. L. (1982). The ulcus-syndrome in cod (Gadus morhua). IV. Transmission experiments with two viruses isolated from cod and Vibrio anguillarum. Nord Veterinaermed. $34: 136-142$

Responsible Subject Editor: W. Ahne, Munich, Germany
McAllister, P. E., Schill, W. B. (1986). Immunoblot assay: a rapid and sensitive method for identification of salmonid viruses. J. Wildl. Dis. 22: 468-474

McArn, G. E., McCain, B., Wellings, S. R. (1978). Skin lesions and associated virus in Pacific cod (Gadus macrocephalus) in the Bering Sea. Fed. Proc. 37: 937

Morrison, C. M., Shum, G., Appy, R. G., Odense, P., Annand, C. (1982). Histology and prevalence of X-cell lesions in Atlantic cod (Gadus morhua). Can J. Fish. Aquat. Sci. 39: $1519-1530$

Olesen, N. J., Lorenzen, N., Jorgensen, P. E. V (1991) Serological differentiation of Egtved virus (VHSV) using neutralizing monoclonal and polyclonal antibodies Abstracts of the Annual Meeting of the European Association of Fish Pathologists, Budapest, Hungary. Fish Culture Research Inst., Szarvas

Reed, L. J., Muench, H. (1938). A simple method of estimating fifty percent endpoints. Am. J. Hyg. 27: 493-502

Reno, P. W., Nicholson, B. L. (1980). Viral erythrocytic necrosis (VEN) in Atlantic cod (Gadus morhua): in vitro studies Can. J. Fish. Aquat. Sci. 37: 2276-2281

Stewart, B. B., Olson, C., Lutz, S. (1990). VHS virus detected at Lummi Bay Sea Ponds, Bellingham, Washington. Fish Health Sect. Am. Fish. Soc. Newsl. 18 (1): 2

Vestergard Jorgensen, P. E., Olesen, N. J. (1987). Cod ulcus syndrome rhabdovirus is indistinguishable from the Egtved (VHS) virus. Bull. Eur. Ass. Fish Pathol. 7: 73-74

Walker, R., Sherburne, S. W. (1977). Piscine erythrocytic necrosis virus in Atlantic cod, Gadus morhua, and other fish: ultrastructure and distribution. J. Fish. Res. Bd Can. 34: 1188-1195

Winton, J. R., Batts, W., Deering, R., Brunson, R., Hopper, K., Nishizawa, T., Stehr, C. (1991). Characteristics of the first North American isolates of viral hemorrhagic septicemia virus. Second International Symposium on Viruses of Lower Vertebrates, Corvallis, Oregon. Oregon State University, Corvallis

Winton, J. R., Batts, W. N., Nishizawa, T., Stehr, C. M. (1989) Characterization of the first North American isolates of viral hemorrhagic septicemia virus. Fish Health Sect. Am Fish. Soc. Newsl. 17 (2): 2

Wolf, K. (1988). Fish viruses and fish viral diseases. Cornell Univ. Press, Ithaca

Wolf, K., Gravell, M., Malsberger, R. G. (1966). Lymphocystis virus: isolation and propagation in centrarchid fish cell lines. Science 151: 1004-1005

Manuscript first received: July 25, 1991

Revised version accepted: February 10, 1992 